\title{
Health status and gerontological evaluation in Mexican older adults in the face of the COVID-19 pandemic
}

\author{
Eduardo Guzmán-Olea, ${ }^{1 *}$ Raúl A. Agis-Juárez, ${ }^{2}$ Víctor H. Bermúdez-Morales, ${ }^{3}$ Kirvis Torres-Poveda, ${ }^{4}$ \\ Vicente Madrid-Marina, ${ }^{3}$ David López-Romero ${ }^{2}$ and Eloy Maya-Pérez ${ }^{5}$ \\ ${ }^{1}$ Consejo Nacional de Ciencia y Tecnología-Universidad Autónoma del Estado de Hidalgo, Hidalgo; ${ }^{2}$ Gerontology Academic Area, Instituto de \\ Ciencias de la Salud, Universidad Autónoma del Estado de Hidalgo, Hidalgo; ${ }^{3}$ Directorate of Chronical Diseases and Cancer, Center of Research \\ on Infectious Diseases, Instituto Nacional de Salud Pública, Morelos; ${ }^{4}$ Consejo Nacional de Ciencia y Tecnología-Instituto Nacional de Salud \\ Pública, Morelos; ${ }^{5}$ Clinical Psychology Academic Area, Universidad de Guanajuato, Campus Celaya-Salvatierra, Guanajuato. Mexico
}

\begin{abstract}
Introduction: Older adults constitute the most vulnerable population group to the COVID-19 pandemic. In Mexico, their biopsychosocial conditions might intensify their vulnerability. Method: Affiliation to health systems, health conditions and gerontological evaluation of 3,218 older adults were analyzed following the methodology of the PAHO-Mexico Health, Well-being and Aging Survey. Results: $88.6 \%$ of older adults referred being affiliated to health systems; $30.2 \%, 52.4 \%, 10.3 \%, 4.1 \%$ and $5.6 \%$ referred suffering from diabetes mellitus, high blood pressure, chronic obstructive pulmonary disease, heart disease and cerebrovascular disease, respectively; $15.6 \%$ reported urinary incontinence, and $11.3 \%$, fecal incontinence; $12.1 \%$ of the women referred having suffered from breast cancer at some point, and $6.3 \%$, cervical cancer. The habit of smoking tobacco was observed in $11.1 \%$, risk of malnutrition in $32.8 \%$, established malnutrition in $4.1 \%$, functional dependence for basic and instrumental activities of daily life in $16.3 \%$ and $17.6 \%$, respectively. Conclusion: Comprehensive gerontological evaluation is essential for efficient care of older adults who suffer from COVID-19, and for adequate care of the effects or health conditions at the conclusion of the confinement imposed by the pandemic.
\end{abstract}

KEY WORDS: Gerontological evaluation. Older adults. COVID-19. SARS-CoV-2. Mexico. Vulnerability.

\section{Estado de salud y valoración gerontológica en adultos mayores mexicanos ante la pandemia por COVID-19}

\section{Resumen}

Introducción: Los adultos mayores constituyen el grupo más vulnerable ante la pandemia por COVID-19; en México, sus condiciones biopsicosociales podrían potenciar su vulnerabilidad. Método: Se analizó afiliación a sistemas de salud, condiciones de salud y evaluación gerontológica de 3218 adultos mayores conforme a la metodología de la Encuesta Salud, Bienestar y Envejecimiento OPS-México. Resultados: 88.6 \% de los adultos mayores refirió afiliación a un sistema de salud; 30.2, 52.4, 10.3, 4.1 y $5.6 \%$ indicaron padecer diabetes mellitus, hipertensión arterial, enfermedad pulmonar obstructiva crónica, enfermedad cardiaca y evento vascular cerebral, respectivamente; $15.6 \%$ reportó incontinencia urinaria y $11.3 \%$, fecal; $12.1 \%$ de las mujeres indicó haber padecido en algún momento cáncer de mama y $6.3 \%$, cáncer cervicouterino. Se observó hábito de fumar tabaco en $11.1 \%$, riesgo de malnutrición en 32.8 \%, malnutrición establecida en $4.1 \%$, dependencia funcional para las actividades básicas en $16.3 \%$ e instrumentales de la vida diaria en 17.6 \%. Conclusión: La evaluación

Correspondence:

*Eduardo Guzmán-Olea

E-mail: eguzmanol@ conacyt.mx
Date of reception: 01-07-2020

Date of acceptance: 06-07-2020

DOI: 10.24875 /GMM.M20000429
Gac Med Mex. 2020;156:412-417

Contents available at PubMed

www.gacetamedicademexico.com

0016-3813/@ 2020 Academia Nacional de Medicina de México, A.C.. Published by Permanyer. This is an open access article under the CC BY-NC-ND license (http://creativecommons.org/licenses/by-nc-nd/4.0/). 
gerontológica integral es fundamental para la atención eficiente de los adultos mayores que padecen COVID-19 y para la adecuada atención por los efectos o condiciones de salud al terminar el confinamiento por la pandemia.

PALABRAS CLAVE: Evaluación gerontológica. Adultos mayores. COVID-19. SARS-CoV-2. México. Vulnerabilidad.

\section{Introduction}

In late 2019, the coronavirus disease (COVID-19) emerged in the People's Republic of China, caused by the severe acute respiratory syndrome coronavirus 2 (SARS-CoV-2); on March 11, 2020 the World Health Organization decreed the emergence of the pandemic. ${ }^{1,2}$ Initial reports referred febrile syndrome and respiratory symptoms as clinical manifestations of the disease; subsequently, pulmonary inflammatory activity, circulatory disorders, venous thrombosis, gastrointestinal symptoms, intracerebral hemorrhage, as well as neurological and muscular manifestations were included. ${ }^{3-5}$

On the other hand, owing to the latent risk of infection in all population groups, the World Health Organization proposed general protocols of action for the control and containment of the disease; ${ }^{6}$ however, thanks to international epidemiological reports, people aged 60 years and older, those who suffer from chronic diseases -mainly high blood pressure, diabetes, obesity, kidney, respiratory and heart diseases-, those with immune compromise and smokers, were determined to be at higher risk of death when suffering from COVID-19. ${ }^{7-10}$ In this sense, given that Mexico has 15.4 million older adults (OAs), ${ }^{11}$ and most main causes of morbidity and mortality in said age group are reported as risk factors in case of SARS-CoV-2 infection, this is a highly vulnerable population sector. $^{12-13}$

When the first case of COVID-19 was confirmed in Mexico, ${ }^{14}$ the Ministry of Health implemented general measures to contain the pandemic, but given the significant increase in the number of cases, national measures were implemented, which included the suspension of educational activities, mass events and non-essential activities; the Jornada Nacional de Sana Distancia (National Campaign for Healthy Distance) was established, focused on promoting social distancing in order to reduce the frequency of contact between people and reduce the risk of propagation of the disease. At the beginning of phase 2 of the pandemic, home confinement of the population was established, with an emphasis on the older adult population (60 years and older), as well as on people diagnosed with high blood pressure, diabetes, heart or pulmonary conditions, or immunosuppression. ${ }^{15-17}$

Given that more than half the OAs in Mexico lack a pension and are forced to work (mainly in the informal sector), the State has implemented economic support programs for people older than 68 years. To favor this measure, two two-month payments of this economic stimulus were given in advance at the beginning of confinement; however approximately $26 \%$ of OAs lack said social support, which forces them to work and fail to comply with social isolation, with the consequent exposure to contract COVID-19. ${ }^{18}$

Subsequently, a few days after the National Campaign for Healthy Distance was concluded by the Mexican government, the highest number of deaths in 24 hours (so far) was recorded, which placed the country at first place in the world for COVID-19 deaths within the previous 24 hours; up to that date, Mexico had accumulated 101,238 infected subjects (confirmed), out of which $20.38 \%$ corresponded to OAs, amongst which $64.2 \%$ required hospitalization and, of those who remained hospitalized, $90.04 \%$ died. Overall, up to that moment, $29.6 \%$ of all deaths recorded in the country corresponded to OAs. ${ }^{19}$

The purpose of this work is to describe the health and functional conditions of Mexican older adults prior to the start of the pandemic caused by SARS-CoV-2, which will allow offering an overview of the biopsychosocial conditions of the older adult population of Mexico, in order to support a comprehensive care approach during the pandemic and post-confinement.

\section{Method}

With a descriptive, cross-sectional design, information obtained from interviews and gerontological evaluations of 3,218 OAs from Hidalgo, Puebla, Tlaxcala, State of Mexico, Morelos and Mexico City, who participated in the University Program for Gerontological Care between 2018-2019, was analyzed. Using the methodology and instruments of the Health, Well-being and Aging Survey (SABE-México), validated for the Mexican population, ${ }^{12,20}$ sociodemographic and affiliation data, and self-reports about suffering from diabetes mellitus, high blood pressure, chronic obstructive 
pulmonary disease, heart diseases, cerebrovascular event, cancer and fecal and urinary incontinence were reviewed. Evaluations addressed depressive symptoms (Yesavage's Geriatric Depression Scale), nutritional status (Guigoz and Velas Mini Nutritional Assessment scale), dependence to carry out basic activities of daily living (BADL, using the Katz Index of Independence in Basic Activities of Daily Living), dependence for the performance of instrumental activities of daily living (IADL, with Lawton and Brody Instrumental Activities of Daily Living Index) ${ }^{21}$ and, additionally, the tobacco smoking habit.

The interviews and evaluations were carried out by pairs of students from the Gerontology Academic Area of the Autonomous University of the State of Hidalgo, under the supervision of professors and researchers from this institution. The researchers were previously trained in the SABE-Mexico Survey program, by the Deputy Directorate for the Care of Aging of the National Center for Preventive Programs and Disease Control (CENAPRECE - Centro Nacional de Programas Preventivos y Control de Enfermedades) of the Ministry of Health.

The analyzed sociodemographic data and their categories included age ( 60 to $69, \geq 70$ years), gender, place of residence (urban and rural), employment (works, does not work and other), marital status (married and other), and level of education (basic or lower or higher than basic). Regarding the presence of comorbidities, self-reference of each one of them by clinical diagnosis was considered. As for cancer, only breast and cervical cancer were considered in women, as well as prostate cancer in men; previous or current presence of these conditions was considered for the record.

Gerontological evaluations categorization was established as follows:

- Depression: no depression, mild to moderate, and severe depression.

- Nutritional status: normal status, malnutrition risk and malnutrition.

- Functional dependence for BADL and IADL: no impairment, mild to moderate impairment and severe impairment.

All analyses and interpretations were carried out by specialists from each area. Data descriptive and dispersion analyses were carried out, and data were represented as means and proportions, considering the standard error and a level of significance of $95 \%$ $(p<0.05)$; the processing was carried out using the SPSS statistical package, version 16 .
The project was carried out considering the recommendations of the 1964 Declaration of Helsinki and the ethical guidelines established by the Ministry of Health. At the beginning of each interview, the subjects were informed about and invited to participate in the University Program for Gerontological Care; those who accepted, signed an informed consent letter, without refusal to participate affecting their care, evaluation and follow-up within the program. The project was reviewed and approved by the Research and Ethics Commission of the Autonomous University of Hidalgo Gerontology Academic Area.

\section{Results}

From an initial selection among 3,425 OAs, a final sample of 3,218 was obtained. The participants were residents of urban and rural areas and were between 60 and 105 years old at the time of the study. The program they attended does not depend on any health institution. Initially, affiliation to social security was determined in $88.6 \%$ of participants; significantly, a higher predominance of women, residents of urban areas and people with employment was observed and, in those who had some education, it was higher than basic (Table 1).

Regarding the analysis of the main chronic diseases referred to as risk factors for COVID-19, type 2 diabetes mellitus was identified in $30.2 \%$ of OAs, with statistical significance in people aged 60 to 69 years, residents of urban areas, with a job, married and with basic or lower education. High blood pressure was ranked as the comorbidity with the highest prevalence (52.4\%); a higher predominance was observed in men, people with employment and with a basic or lower education level. Chronic obstructive pulmonary disease was determined in $10.3 \%$, while heart diseases only in $4.1 \%$, with a higher predominance in men. Finally, $5.6 \%$ reported having suffered at least one cerebrovascular disease event (Table 2).

Regarding cancer, $12.1 \%$ of women referred suffering or having suffered from breast cancer, while $6.3 \%$ indicated the same for cervical cancer; in the case of men, $11.4 \%$ reported suffering or having suffered from prostate cancer. Urinary incontinence was referred by $15.6 \%$ of OAs, while $11.3 \%$ referred fecal incontinence (Table 3).

Gerontological evaluations results allowed obtaining evidence of depressive symptoms in $26.5 \%$ of total subjects: $19.7 \%$ with mild to moderate level, and $6.8 \%$, severe level. With regard to nutritional status, 
Table 1. Sociodemographic characteristics of Mexican older adults participating in the University Program for Gerontological Care

\begin{tabular}{|c|c|c|c|c|c|c|c|c|c|c|c|c|}
\hline \multirow[t]{2}{*}{ Characteristic } & \multicolumn{2}{|c|}{ Age (years) } & \multicolumn{2}{|c|}{ Gender } & \multicolumn{2}{|c|}{ Residence } & \multicolumn{2}{|c|}{ Employment } & \multicolumn{2}{|c|}{ Marital status } & \multicolumn{2}{|c|}{ Education } \\
\hline & $60-69$ & $\geq 70$ & $F$ & M & U & $\mathbf{R}$ & W & NW & M & 0 & $\leq \mathrm{B}$ & $>\mathrm{B}$ \\
\hline $\begin{array}{l}\text { Population }(n=3218,100 \%) \\
n(\%)\end{array}$ & $\begin{array}{l}1580 \\
(49.1)\end{array}$ & $\begin{array}{r}1638 \\
(50.9)\end{array}$ & $\begin{array}{l}2204 \\
(68.5)\end{array}$ & $\begin{array}{l}1014 \\
(31.5)\end{array}$ & $\begin{array}{l}2037 \\
(63.3)\end{array}$ & $\begin{array}{c}1181 \\
(36.7)\end{array}$ & $\begin{array}{l}2275 \\
(70.7)\end{array}$ & $\begin{array}{c}943 \\
(29.3)\end{array}$ & $\begin{array}{l}2838 \\
(88.2)\end{array}$ & $\begin{array}{c}380 \\
(11.8)\end{array}$ & $\begin{array}{l}2040 \\
(63.4)\end{array}$ & $\begin{array}{l}1178 \\
(36.6)\end{array}$ \\
\hline $\begin{array}{l}\text { Affiliation ( } n=2851,88.6 \% \text { ) } \\
n(\%)\end{array}$ & $\begin{array}{c}1374 \\
(48.2)\end{array}$ & $\begin{array}{c}1477 \\
(51.8)\end{array}$ & $\begin{array}{l}2061^{\S} \\
(72.3)\end{array}$ & $\begin{array}{c}790 \\
(27.7)\end{array}$ & $\begin{array}{c}1796^{\S} \\
(63)\end{array}$ & $\begin{array}{l}1055 \\
(37)\end{array}$ & $\begin{array}{l}1955^{\S} \\
(68.6)\end{array}$ & $\begin{array}{c}896 \\
(31.4)\end{array}$ & $\begin{array}{l}2589 \\
(90.8)\end{array}$ & $\begin{array}{l}262 \\
(9.2)\end{array}$ & $\begin{array}{c}1702 \\
(59.7)\end{array}$ & $\begin{array}{r}1149 \\
(40.3)\end{array}$ \\
\hline
\end{tabular}

$\mathrm{F}=$ females, $\mathrm{M}=$ males, $\mathrm{U}=$ urban, $\mathrm{R}=$ rural, $\mathrm{W}=$ works, $\mathrm{NW}=$ does not work, $\mathrm{M}=$ married, $\mathrm{O}=$ other (single, widowed), $\leq \mathrm{B}=$ basic (complete primary school) or lower than basic education; > B = higher than basic education (secondary school, high school, technical or college degree). According to the National Institute of Statistics and Geography, a settlement is regarded as rural when it has less than 2500 inhabitants.

§Statistically significant difference between groups with $p<0.05$.

Table 2. Main pathologies in 3218 older adults participating in the University Program for Gerontological Care

\begin{tabular}{|c|c|c|c|c|c|c|c|c|c|c|}
\hline \multirow[t]{2}{*}{ Variable } & \multicolumn{2}{|c|}{ DM n = $972(30.2 \%)$} & \multicolumn{2}{|c|}{ HBP $n=1686(52.4 \%)$} & \multicolumn{2}{|c|}{ COPD $n=331(10.3 \%)$} & \multicolumn{2}{|c|}{ HD $n=132(4.1 \%)$} & \multicolumn{2}{|c|}{ CVE $n=181(5.6 \%)$} \\
\hline & $\mathbf{P}(\%)$ & NP (\%) & $\mathbf{P}(\%)$ & NP (\%) & $\mathbf{P}(\%)$ & NP (\%) & $\mathbf{P}(\%)$ & NP $(\%)$ & $\mathbf{P}(\%)$ & NP (\%) \\
\hline $\begin{array}{l}\text { Age, years } \\
60-69 \\
\geq 70\end{array}$ & $\begin{array}{l}16.8^{\S} \\
13.4\end{array}$ & $\begin{array}{l}32.3 \\
37.5\end{array}$ & $\begin{array}{l}24.9 \\
27.5\end{array}$ & $\begin{array}{l}24.2 \\
23.4\end{array}$ & $\begin{array}{l}4.9 \\
5.4\end{array}$ & $\begin{array}{l}44.2 \\
45.5\end{array}$ & $\begin{array}{l}1.2 \\
2.9\end{array}$ & $\begin{array}{c}47.9 \\
48\end{array}$ & $\begin{array}{l}3.2 \\
2.4\end{array}$ & $\begin{array}{l}45.9 \\
48.5\end{array}$ \\
\hline $\begin{array}{l}\text { Gender } \\
\text { F } \\
\text { M }\end{array}$ & $\begin{array}{l}15.9 \\
14.3\end{array}$ & $\begin{array}{l}52.6 \\
17.2\end{array}$ & $\begin{array}{c}23.8 \\
28.6^{\S}\end{array}$ & $\begin{array}{c}44.7 \\
2.9\end{array}$ & $\begin{array}{l}5.2 \\
5.1\end{array}$ & $\begin{array}{l}63.2 \\
26.4\end{array}$ & $\begin{array}{l}1.5 \\
2.6^{\S}\end{array}$ & $\begin{array}{c}67 \\
28.9\end{array}$ & $\begin{array}{c}2.6 \\
3\end{array}$ & $\begin{array}{l}65.9 \\
28.5\end{array}$ \\
\hline $\begin{array}{l}\text { Residence } \\
\text { U } \\
\mathrm{R}\end{array}$ & $\begin{array}{l}17.3^{\S} \\
12.9\end{array}$ & $\begin{array}{c}46 \\
23.8\end{array}$ & $\begin{array}{l}29.2 \\
23.2\end{array}$ & $\begin{array}{l}34.1 \\
13.5\end{array}$ & $\begin{array}{c}5 \\
5.3\end{array}$ & $\begin{array}{l}58.3 \\
31.4\end{array}$ & $\begin{array}{l}2.3 \\
1.8\end{array}$ & $\begin{array}{c}61 \\
34.9\end{array}$ & $\begin{array}{l}3.4 \\
2.2\end{array}$ & $\begin{array}{l}59.9 \\
34.5\end{array}$ \\
\hline $\begin{array}{l}\text { Employment } \\
\text { W } \\
\text { NW }\end{array}$ & $\begin{array}{l}17.9 \S \\
12.3\end{array}$ & $\begin{array}{c}52.8^{\S} \\
17\end{array}$ & $\begin{array}{c}31.4 \\
21\end{array}$ & $\begin{array}{c}39.3 \\
8.3\end{array}$ & $\begin{array}{l}6.8 \\
3.5\end{array}$ & $\begin{array}{l}63.9 \\
25.8\end{array}$ & $\begin{array}{l}2.7 \\
1.4\end{array}$ & $\begin{array}{c}68 \\
27.9\end{array}$ & $\begin{array}{c}3.6 \\
2\end{array}$ & $\begin{array}{l}67.1 \\
27.3\end{array}$ \\
\hline $\begin{array}{l}\text { Marital statu } \\
\text { M } \\
0\end{array}$ & $\begin{array}{c}22.6^{\S} \\
7.6\end{array}$ & $\begin{array}{c}65.6 \\
4.2\end{array}$ & $\begin{array}{c}43.5 \\
8.9\end{array}$ & $\begin{array}{c}44.7 \\
2.9\end{array}$ & $\begin{array}{l}6.2 \\
4.1\end{array}$ & $\begin{array}{l}82 \\
7.7\end{array}$ & $\begin{array}{l}2.2 \\
1.9\end{array}$ & $\begin{array}{l}86 \\
9.9\end{array}$ & $\begin{array}{l}2.9 \\
2.7\end{array}$ & $\begin{array}{c}85.3 \\
9.1\end{array}$ \\
\hline $\begin{array}{l}\text { Education } \\
\leq \mathrm{B} \\
>\mathrm{B}\end{array}$ & $\begin{array}{c}20.8^{\S} \\
9.4\end{array}$ & $\begin{array}{c}42.6^{\S} \\
27.2\end{array}$ & $\begin{array}{l}35.6 \\
16.8\end{array}$ & $\begin{array}{l}27.8 \\
19.8\end{array}$ & $\begin{array}{l}5.5 \\
4.8\end{array}$ & $\begin{array}{l}57.9 \\
31.8\end{array}$ & $\begin{array}{c}2 \\
2.1\end{array}$ & $\begin{array}{l}61.4 \\
34.5\end{array}$ & $\begin{array}{l}3.1 \\
2.5\end{array}$ & $\begin{array}{l}60.3 \\
34.1\end{array}$ \\
\hline
\end{tabular}

$\mathrm{DM}=$ diabetes mellitus, $\mathrm{HBP}=$ high blood pressure, $\mathrm{COPD}=$ chronic obstructive pulmonary disease, $\mathrm{HD}=$ heart disease, $\mathrm{CVE}=$ cerebrovascular event, $\mathrm{P}=$ presented, $\mathrm{NP}=$ not presented, $\mathrm{F}=$ females, $\mathrm{M}=$ males, $\mathrm{U}=$ urban, $\mathrm{R}=$ rural, $\mathrm{W}=$ works, $\mathrm{NW}=$ does not work, $\mathrm{M}=$ married, $\mathrm{O}=$ other (single, widowed), $\leq \mathrm{B}=$ basic (complete primary school) or lower than basic education; $>\mathrm{B}=$ higher than basic education.

statistically significant difference between groups with $p<0.05$.

Table 3. Previous or current presence of cancer, urinary and fecal incontinence and smoking habit in $\mathbf{3 2 1 8}$ older adults

\begin{tabular}{l|c|c|c|c|c|c|}
\multirow{2}{*}{ Condition } & \multicolumn{3}{|c|}{ Cancer referred } & \multicolumn{2}{c|}{ Incontinence } \\
\cline { 2 - 7 } & Breast* & Cervix* & Prostate** $^{*}$ & Urinary & Fecal \\
\cline { 2 - 7 } & $\%(95 \% \mathrm{Cl})$ & $\%(95 \% \mathrm{Cl})$ & $\%(95 \% \mathrm{Cl})$ & $\%(95 \% \mathrm{Cl})$ & $\%(95 \% \mathrm{Cl})$ & $\%(95 \% \mathrm{Cl})$ \\
\hline Referred & $12.1(11.6-12.9)$ & $6.3(5.8-7.1)$ & $11.4(10.8-12.2)$ & $15.6(14.9-16.2)$ & $11.3(10.6-12.1)$ & $11.1(10.3-11.8)$ \\
\hline Not referred & $87.9(86.2-88.8)$ & $93.7(92.9-94.3)$ & $88.6(87.8-89.4)$ & $84.4(83.7-85.2)$ & $88.7(87.6-89.9)$ & $88.9(87.7-90.2)$ \\
\hline Difference $p$-value & 0.00 & 0.00 & 0.00 & 0.00 & 0.00 & 0.03
\end{tabular}

*Only in females. **Only in males. Females, $n=2204$ (68.5\%); males, $n=1014$ (31.5\%).

$\mathrm{Cl}=$ confidence interval. 
Table 4. Gerontological evaluation of $\mathbf{3 2 1 8}$ older adults

\begin{tabular}{|c|c|c|c|c|c|c|c|c|}
\hline \multirow[t]{3}{*}{ Evaluation } & \multirow{2}{*}{\multicolumn{2}{|c|}{ Depressive symptoms \% }} & \multirow{2}{*}{\multicolumn{2}{|c|}{ Nutritional status \% }} & \multicolumn{4}{|c|}{ Functional dependence } \\
\hline & & & & & \multicolumn{2}{|c|}{ BADL $\%$} & \multicolumn{2}{|c|}{ IADL \% } \\
\hline & $\begin{array}{l}\text { Milld-Mod. } \\
\text { (95\% Cl) }\end{array}$ & $\begin{array}{c}\text { Severe } \\
(95 \% \mathrm{CI})\end{array}$ & $\begin{array}{c}\text { MNR } \\
(95 \% \mathrm{CI})\end{array}$ & $\begin{array}{c}\mathrm{Mn} \\
(95 \% \mathrm{Cl})\end{array}$ & $\begin{array}{l}\text { Mild-Mod. } \\
(95 \% \text { Cl) }\end{array}$ & $\begin{array}{c}\text { Severe } \\
(95 \% \mathrm{Cl})\end{array}$ & $\begin{array}{l}\text { Mild-Mod. } \\
(95 \% \text { Cl) }\end{array}$ & $\begin{array}{l}\text { Severe } \\
(95 \% \mathrm{Cl})\end{array}$ \\
\hline Present & $19.7(19.1-20.2)$ & $6.8(5.9-7.4)$ & $32.8(31.2-33.7)$ & $4.1(3.2-5)$ & $12.9(11.8-13.7)$ & $3.4(2.2-4.1)$ & $16.2(15.1-17.3)$ & $1.4(0.8-2.1)$ \\
\hline Not present & \multicolumn{2}{|c|}{$73.5(72.1-74.3)$} & \multicolumn{2}{|c|}{$63.1(61.9-64.5)$} & \multicolumn{2}{|c|}{$83.7(82.6-84.9)$} & \multicolumn{2}{|c|}{$82.4(80.9-84)$} \\
\hline $\begin{array}{l}\text { Difference } \\
\text { p-value }\end{array}$ & 0.00 & 0.00 & 0.00 & 0.00 & 0.00 & 0.00 & 0.00 & 0.00 \\
\hline
\end{tabular}

$32.8 \%$ showed malnutrition risk, while $4.1 \%$ had established malnutrition. Regarding functional dependence for BADL (e.g., personal hygiene and grooming, dressing, eating, functional mobility, etc.), $12.9 \%$ had mild to moderate dependence, while $3.4 \%$ had severe dependence; as for functional dependence for IADLs (use of the telephone, handling of medications, performing domestic chores, etc.), $16.2 \%$ indicated mild to moderate dependence, and $1.4 \%$, severe dependence (Table 4).

\section{Discussion}

Biopsychosocial conditions of OAs in Mexico place them as one of the most vulnerable sectors to COVID-19 in our country. The evident efforts to know the health conditions of this sector are insufficient given the current situation. A comprehensive analysis must be carried out that also involves socioeconomic conditions and conditions of independence and functionality.

The need for having social security in terms of health is not covered by affiliation alone, since although the level of coverage is wide, deficiencies in the quality of care, lack of accessibility to institutions and specialists, shortage of health personnel and discontinuation of medication for preexisting conditions (such as high blood pressure, diabetes, cancer and cardiovascular diseases), drive to the search for other public and/or private institutions, which might generate higher exposure to SARS-CoV-2, increase the risk of transmission and generate out-of-pocket expenses, which given the current situation, could be catastrophic for OAs. ${ }^{22-25}$ Given the complexity in OAs individual conditions, such as chronicity of multiple pathologies, polypharmacy, frailty, dependence and socioeconomic vulnerability, a multidisciplinary care approach is necessary in the event of suffering from COVID-19.
The contributions herein presented enable pointing out that OAs with disabling conditions or dependence might have a poor prognosis in their recovery or a fatal outcome in case of SARS-CoV-2 infection. In patients with nutritional deficiencies in whom mechanical ventilation is necessary, subsequent dysphagia represents an essential element for rehabilitation and survival. ${ }^{26}$ Depressive symptoms might be affected by social isolation, and even evolve and cause mild cognitive impairment and suicide attempts. ${ }^{27-28}$ Functional dependence for basic and instrumental activities of daily living could affect compliance with the measures of hygiene and isolation that are necessary to prevent transmission, as well as nutritional status, rational use of medications, physical condition and motor skills.

Finally, with all of the above, our view is focused on showing the biopsychosocial complications OAs face and will face in pandemic and post-COVID-19 times. Based on the gerontological evaluation that was carried out, ideas on the redesign and adaptation of the health education system in Mexico to current conditions, the generation of new professional profiles, implementation of programs based on self-care empowerment, the training of primary caregivers, as well as the design of care plans based on the promotion of autonomy, are strengthened. ${ }^{29-33}$

\section{Conclusions}

OAs constitute the most vulnerable population group to the COVID-19 pandemic, mainly due to processes that are inherent to aging (e.g., chronic inflammation and immunosenescence). The condition of vulnerability of the Mexican population older than 60 years increases due to their biopsychosocial characteristics, such as the complexity of their ailments, the development of conditions of disability or dependence, and the economic 
vulnerability they experience. In view of the current conditions, it is essential to have a comprehensive diagnosis of OAs, which allows the most appropriate approach and intervention during the pandemic in those cases with COVID-19, to efficiently address established or increased chronicity of preexisting conditions. Developing intervention strategies based on the person, focusing on self-care processes and actions that enable autonomy, will also be necessary.

\section{Acknowledgements}

To the CENAPRECE National Program for the Care of Aging (Ministry of Health), for the training for surveys and evaluations application. To the survey takers and evaluators of the Universidad Autónoma del Estado de Hidalgo Gerontology Academic Area.

\section{Conflict of interests}

The authors declare that they have no conflicts of interest.

\section{Funding}

The project was financed by recurring support granted by the Universidad Autónoma del Estado de Hidalgo.

\section{Ethical disclosures}

Protection of human and animal subjects. The authors declare that no experiments were performed on humans or animals for this research.

Confidentiality of data. The authors declare that they followed the protocols of their work center on the publication of third-party data.

Right to privacy and informed consent. The authors have obtained informed consent from the patients and/or subjects referred to in the article. This document is in the possession of the corresponding author.

\section{References}

1. World Health Organization. Coronavirus disease (COVID-19) pandemic Switzerland: World Health Organization; 2020.

2. Cucinotta D, Vanelli M. WHO declares COVID-19 a pandemic. Acta Biomed. 2020;91:157-160.

3. Mao L, Wang M, Chen S, He Q, Chang J, Hong C, et al. Neurological manifestations of hospitalized patients with COVID-19 in Wuhan, China: a retrospective case series study. medRxiv. 2020.

4. Jiménez-Ruiz A, García-Grimshaw M, Ruiz-Sandoval JL. Neurologic manifestations of COVID-19. Gac Med Mex. 2020;156:258.
5. Schmulson M, Dávalos MF, Berumen J. Alerta: los síntomas gastrointestinales podrían ser una manifestación de la COVID-19. Rev Gastroenterol Mex. 2020;85:282-287.

6. World Health Organization. What are the international health regulations and emergency committees? Switzerland: World Health Organization; 2019.

7. Zhou F, Yu T, Du R, Fan G, Liu Y, Liu Z, et al. Clinical course and risk factors for mortality of adult inpatients with COVID-19 in Wuhan, China: a retrospective cohort study. Lancet. 2020;395:1054-1062.

8. Huang $\mathrm{C}$, Wang $\mathrm{Y}$, Li X, Ren L, Zhao J, Hu Y, et al. Clinical features of patients infected with 2019 novel coronavirus in Wuhan, China. Lancet. 2020;6736:1-10

9. Fang J, Liehua D, Lianging Z, Cai Y, Cheung CW, Xia Z. Review of the clinical characteristics of coronavirus disease 2019 (COVID-19). J Gen Intern Med. 2020;5:1545-1549.

10. Secretaría de Salud [Internet]. Mexico: Nuevo coronavirus 2019 nCoV-Comunicado técnico diario; 2020.

11. Instituto Nacional de Estadística, Geografía e Informática [Internet]. Mexico: Estadísticas a propósito del Día Internacional de las Personas de Edad. Datos nacionales; 2019

12. Secretaría de Salud. Encuesta Salud, Bienestar y Envejecimiento SABE. Mexico: SSa; 2017.

13. Guzmán-Olea E, López-Romero D, Torres-Poveda K, Madrid-Marina V, Luna-Muñoz J, Pimentel-Pérez BM, et al. Condiciones biopsicosociales de adultos mayores mexicanos con diabetes mellitus. Gac Med Mex. 2017;153:794-799.

14. Secretaría de Salud [Internet]. Mexico: Aviso epidemiológico-2020. Enfermedad COVID-19 por SARS-CoV-2; 2020.

15. Secretaría de Salud [Internet]. Mexico: Sana distancia COVID-19; 2020.

16. Ornelas-Aguirre JM. El nuevo coronavirus que llegó de Oriente: análisis de la epidemia inicial en México. Gac Med Mex. 2020:208-216.

17. Suárez V, Suárez-Quezada M, Oros-Ruiz S, Ronquillo-de Jesús E. Epidemiología de COVID-19 en México: del 27 febrero al 30 de abril de 2020. Rev Clin Esp. 2020

18. Secretaría de Bienestar [Internet]. Mexico: Programa para el Bienestar de las Personas Adultas Mayores; 2019.

19. Dirección General de Epidemiología [Internet]. Mexico: Covid-19 México. Información general; 2020

20. Lozano ME, Calleja J, Mena R, et al. Investigación clinicoepidemiológica en envejecimiento: metodología del proyecto Encuesta Salud, Bienestar y Envejecimiento (SABE) en México. Rev Soc Peru Med Interna. 2011:24:186-198.

21. Secretaría de Salud. Principios del abordaje gerontológico en la persona adulta mayor e intervenciones básicas. Mexico: Secretaría de Salud/Centro Nacional de Programas Preventivos y Control de Enfermedades; 2012.

22. Guzmán-Olea E, Maya-Pérez E, López-Romero D, Torres-Poveda K, Bermúdez-Morales VH, Madrid Marina V, et al. Cobertura y eficiencia en atención a las principales enfermedades de adultos mayores de Hidalgo, México. Acta Universitaria. 2018:28:33-39.

23. World Health Organization [Internet]. Switzerland: COVID-19 significantly impacts health services for noncommunicable diseases; 2020.

24. Pavón-León P, Reyes-Morales H, Martínez A, Méndez-Maín SM, Gogeascoechea-Trejo MC, Blázquez-Morales MS. Gasto de bolsillo en adultos mayores afiliados a un seguro público de salud en México. Gac Sanit. 2017:31:286-291.

25. Knaul FM, González-Pier E, Gómez-Dantés O, et al. Hacia la cobertura universal en salud: protección social para todos en México. Salud Publica Mex. 2013;55:207-235.

26. Laviano A, Koverech A, Zanetti M. Nutrition support in the time of SARSCoV-2 (COVID-19). Nutrition. 2020;74:110834.

27. Lara $E$, Koyanagi $A$, Domènech-Abella J, Miret $M$, Ayuso-Mateos J, Haro JM. The impact of depression on the development of mild cognitive impairment over 3 years of follow-up: a population-based study. Dement Geriatr Cogn Disord. 2017;43:155-169.

28. Conejero I, Olié E, Courtet P, Calati R. Suicide in older adults: current perspectives. Clin Interv Aging. 2018:13:691-699.

29. Ñamendys-Silva S, Domínguez-Cherit G. Recommendations for the management of critically ill adult patients with COVID-19. Gac Med Mex. 2020;156:247-249.

30. Barajas-Ochoa A, Andrade-Romo JS, Ramos-Santillán VO. Retos para la educación médica en México en los tiempos del COVID-19. Gac Med Mex. 2020;156:254-257.

31. Guzmán-Olea E, Pimentel-Pérez BM, Salas-Casas A, Armenta-Carrasco Al, Oliver-González LB, Agis-Juárez Raúl A. Prevention of physical dependence and cognitive impairment by implementing an early rehabilitation program in institutionalized elderly. Acta Universitaria. 2016;26:53-59.

32. Guzmán-Olea E, Maya-Pérez E, López-Romero D, Torres-Poveda K, Madrid-Marina V, Pimentel-Pérez BM, et al. Eficacia de un programa de empoderamiento en la capacidad de autocuidado de la salud en adultos mayores mexicanos jubilados. Salud \& Sociedad. 2017:8:10-20.

33. Sánchez-Izquierdo M, Santacreu M, Olmos R, Fernández-Ballesteros R. A training intervention to reduce paternalistic care and promote autonomy: a preliminary study. Clin Interv Aging. 2019;14:1515-1525. 